\title{
Approaches and Methods of College Students' Energy Conservation Education in the Context of University Transformation
}

\author{
Yan Bao ${ }^{a}{ }^{*}$, Hongtao $\mathrm{Yu}^{\mathrm{b}}$, Xinming $\mathrm{Hou}^{\mathrm{c}}$ and Shuang Sun ${ }^{\mathrm{d}}$ \\ College of Automation, Shenyang Institute of Engineering, Shenyang Liaoning110136, China \\ adianzixinxi2004@163.com, bneu970773@sohu.com, chou_xinming@sina.com, dss@stu.sie.edu.cn
}

Keyword: Transformation of colleges and universities; College students; Energy conservation and environmental protection; Education methods

\begin{abstract}
In today's world, energy shortage and environmental problems have become the focus of attention of all mankind.As a university, it is imperative to respond to the national call for energy conservation and consumption reduction without delay, further carry out energy conservation education work, continuously improve teachers and students' awareness of energy conservation and environmental protection, and combine their own characteristics to explore effective ways and means to conduct a series of education and commit to building a conservation-oriented and harmonious society.
\end{abstract}

\section{Introduction}

In response to the national energy saving and consumption reduction call and the implementation of the spirit of the Seventeenth National Congress, according to "the State Council's decision on strengthening energy conservation" and "the Ministry of education's notice on building a conservation oriented school" saving energy and protecting the environment have become the common responsibility and joint action of the whole society now. It is related to the vital interests of the people and to the survival and development of the Chinese nation. According to the spirit of the Ministry of Education, energy conservation education is an important part of the national action for energy conservation and emission reduction[1]. As a university, we should combine its own characteristics, improve college students' consciousness of energy saving, explore ways of saving energy education suitable for colleges and universities, adhere to the association of energy saving education with the construction of the conservation oriented campus, and adopt the methods of combining practice, teaching, and so on, conscientiously implement the policy of national resources saving work, so as to reach the goal. To a good educational effect.

\section{The Importance of Energy Saving Education in Colleges and Universities}

energy conservation education is the inevitable requirement of sustainable development strategy for higher education. The Central Committee of the Communist Party of China regards energy conservation as a basic national policy in the new era, and puts equal emphasis on energy development and conservation, and places energy conservation at the top of the energy strategy; among them, in power supply and power consumption, it also puts forward the guideline of increasing sources and reducing expenditure, saving energy and reducing consumption[2].

Under the new situation in which non-renewable energy is increasingly depleted, achieving energy conservation and environmental protection is a matter of merit and benefit for the benefit of social development in the present age[3]. If college students develop a good sense of energy crisis and good energy saving habits in school, they will be welcomed by the employers, can respond well to the national energy saving and consumption reduction call, and effectively carry out energy saving and consumption reduction work. Therefore, as a university, we should take active action to further strengthen the energy saving education for students, it is an important content of how to combine the characteristics of colleges and universities to improve students' consciousness of energy saving. 
Energy saving education is an indispensable part of quality education for college students. In today's world, the quality education for college students is increasingly valued by the education sector. Besides quality education such as daily scientific culture, ideological morality and mental health, the environmental quality with energy saving and environmental protection consciousness should become the basic quality of college students. The international community has begun to look at the issue of energy conservation education from the perspective of sustainable economic and social development, our country is also introducing policies to gradually integrate energy conservation education into various forms of education systems ranging from basic education to higher education, formal education, and non-formal education [4].

Under the new situation, the content of quality education in colleges and universities has been continuously extended, especially the establishment of the concept of sustainable development needs more environmental quality education. Therefore, to carry out energy-saving education is the focus of quality education in colleges and universities. College students are the pillars of social development in tomorrow. Whether they have a scientific world outlook or development concept and whether they have a concept of sustainable development will have a far-reaching impact on the future economic and social development of the country.

\section{Energy-Saving Education Methods and Methods Applicable to Colleges and Universities}

Enhance Students' Sense of Ownership in the Face of Energy Crisis. Educate students to take a serious look at the energy crisis and help students to build awareness of the importance of "energy conservation". Through the analysis of the grim current situation of the global energy crisis, the education of university students must be brave enough to face the reality. At the same time, combined with the problems of low comprehensive energy utilization and serious waste in our country, students should establish a strong awareness of energy crisis and cultivate everyone from me to do good habits of participating in energy conservation, saving a drop of water and electricity .

Precepts and Teaching in Theory and Practice Teaching. Combine the characteristics of daily life of college students in study and teaching. After several years of professional learning, students will enter various industries and enterprises. Especially engineering practice undergraduate colleges are the bases for training engineering practice professionals. Taking the college as an example, the majors are mostly strong electricity, weak electronic, mechanical, mechanical, mechanical and electrical engineering. Most of the students have to learn the basic knowledge of electrician foundation in class. Therefore, when teachers give students such theoretical courses, they can combine energy saving education with the characteristics of the courses. This will enable students to understand the principle of electrical energy conservation in theory and better grasp the energy-saving methods.

In addition, water, electricity, and gas energy education can also be conducted in practical courses such as course design and professional internships. The professional skills courses of students in science and engineering colleges are conducted in laboratories, practice fields or training bases. In practical teaching, teachers can effectively carry out energy conservation education according to the content taught by the curriculum and combining actual conditions. For example, in the practice of motors, electrical operation and CNC machine tools, students should be educated to reduce the light load and no-load operation of the motor as much as possible. Because of the light load and no-load operation, the efficiency of the motor is very low. When doing professional experiments, students can also be educated in the experiment to avoid the computer's standby operation as much as possible and the unloaded operation of some experimental instruments and instruments. After using the instrument, we must remember to turn off the power supply and keep it properly, and increase its service life.

Initiating teaching and research in energy conservation education for students. Taking advantage of teaching and research in universities and research institutes, we actively advocate and encourage university and department students to carry out research on conservation projects on their own, apply the research results to the practice of building a conservation-oriented campus, build demonstration projects, summarize experiences and actively promote. At the same time, teachers 
are encouraged to lead students of this major to conduct research on energy-saving topics in the science and engineering and humanities, and to widely promote research results. For example, the replacement of incandescent street lamps in campus by our college and the independent research and development of solar street lamps by teachers and students, has saved a considerable amount of electricity cost for the school, and also solved the unavoidable waste of campus street lights in the late night.

At the same time, we should encourage the relevant departments, deepen the development of the needs of the discipline construction, and actively promote the construction and development of cross discipline with the core of saving management and saving water and energy saving technology.

Encourage students to carry out energy conservation-themed campus activities. Through the cooperation with the student management department to carry out the energy saving theme activities, the school league committee, the student association and the student association ,put the educational activities of knowledge and technology into the campus activities plan, and actively organize the students to carry out the scientific and technological competition activities such as the society, the speech, the art and art performance and the small invention and small creation on the theme of saving and environmental protection. Carry out the competition between students and classes, set up a number of energy saving typical, to form a good atmosphere of energy saving, waste and shame, and guide the students to compete for energy saving.

Committed to carrying out energy-saving propaganda activities to create a positive and healthy atmosphere of public opinion. Through campus radio, campus websites, college newspapers, magazines, posters, banners, slogans and other carriers, actively promote relevant policies, laws, regulations, and energy-saving related technologies and methods for energy conservation.

Encourage students to actively carry out the activities of creating energy-saving classes, conservation-type dormitories, and conservation-oriented communities. Students should be encouraged to carry out the activities of recycling resources, regularly recycle students' idle books, clothes, stationery and so on, and contribute to the hope project and the poverty-stricken areas at the right time.

\section{University Students' Energy-saving Education Goal}

The goals of environmental education in universities are based on the understanding, knowledge, attitudes, skills, evaluation capabilities, and reference to the six goals proposed by the Tbilisi Conference. According to the spirit of environmental education goals, the energy conservation education target system should include the following: First, energy conservation knowledge, students through various ways to learn energy saving knowledge, laws and regulations, the environment, ecology, meteorology and other basic knowledge, understand the state policies and regulations on energy conservation through various ways .The second is awareness of energy conservation. Students, on the basis of grasping the basic knowledge of energy conservation, actively guide students to respect energy conservation, concern for energy conservation, understand energy conservation ideologically, consciously and emotionally, and then form an accurate attitude toward energy conservation. The third is the skills of energy saving. Through demonstrations, operations, and preaching and teaching, as well as on-site visits by students and personal practices, teachers have the ability to solve new energy-saving problems and fully grasp energy-saving knowledge and skills [4].

\section{Conclusion}

Under the new energy situation, it is required that colleges and universities should effectively carry out energy saving education, which not only cultivate the energy saving consciousness of the students and make them develop good energy saving habits, but also make students master some energy saving methods.

Moreover, energy conservation is an obligation that every citizen should fulfill. Energy 
conservation depends on the joint efforts of the whole society. It is necessary to carry out extensive and lasting promotion and education of energy conservation, understand the national conditions correctly, set up the consciousness of resource anxiety, and enhance consciousness of self-conscious energy saving. As a social group with higher cultural level, the quality of energy-saving consciousness of college students directly influences the level of social energy-saving consciousness, and has an important demonstration of the energy-saving scope of the entire society [5].

\section{Acknowledgement}

This work was supported in part by Liaoning Province Education Science "13th Five-Year Plan" project under Grant No. JG17DB343, No. JG17DB354, No. JG17DB347 and No. JG17DB344.

\section{References}

[1] Sun Chongli. On energy conservation in colleges and universities. Energy saving economy. 2008,12: 27-28.

[2] $\mathrm{Xu}$ Zhenqi. How to develop energy-saving education under the new situation. University logistics research. 2011, 4: 78-80.

[3] Yan Hong. Citizen energy saving education problem. Energy saving, 2003, 12: 36-38.

[4] Huang Yiqun. The significance and goal of education in energy conservation and emission reduction in colleges and universities are briefly analyzed. Success (education). 2008,5: 21-22.

[5] Wang Xiaohua. Investigation and evaluation on college students 'awareness and behavior of energy conservation. Energy saving technology, 2007,5: 55-57. 